\title{
Politieke strategieë van aktiviste vir die amptelike erkenning van Afrikaans
}

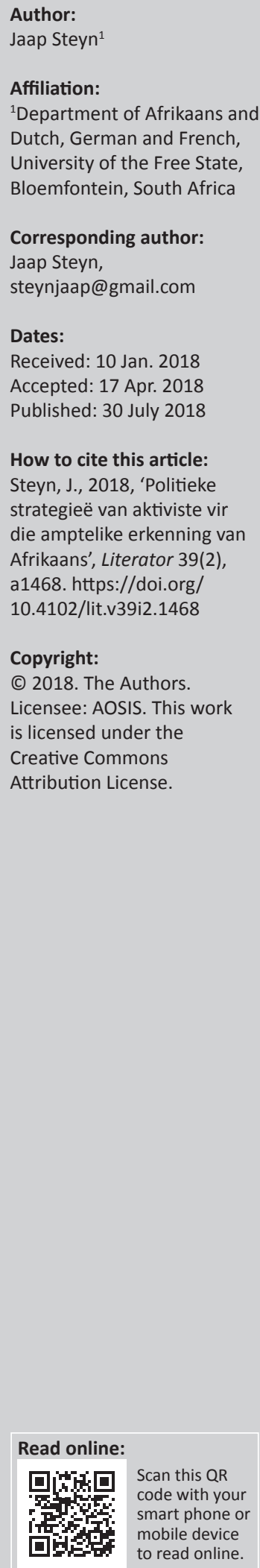

\begin{abstract}
Political strategies of activists for the official recognition of Afrikaans. Five language activists followed different political strategies between 1875 and 1925 to ensure Afrikaans became one of the official languages of South Africa. S.J. du Toit tried to promote Afrikaans, but realised that in the nineteenth century Cape Colony, he could only do it by helping the Dutch advocates acquire several rights. Through the apt manoeuvrings at the National Convention in 1908, General J.B.M. Hertzog and President M.T. Steyn secured official status for Dutch and English in the Union of South Africa, as well as the equal treatment of these two languages. Without language equality, official recognition could easily exist only in name. By choosing a language design, they also ensured that the final recognition of Afrikaans was merely a formality. J.H.H. de Waal and C.J. Langenhoven were the only important activists who were outright anti-Dutch. Through their political actions, they established Afrikaans for certain functions, even before official recognition. Langenhoven also accelerated the standardisation of Afrikaans, thus facilitating official recognition.
\end{abstract}

\section{Inleiding}

Wannie Carstens is 'n prominente aktivis vir veeltaligheid en die gebruik van Afrikaans as universiteitstaal en in ander belangrike funksies. In een van sy jongste artikels stel hy die vraag of 'n derde Afrikaanse taalbeweging nie dalk nodig is nie (Carstens 2018).

Dit is dus gepas om in hierdie huldigingsbundel op die taalaktivisme van die negentiende- en twintigste-eeuse Afrikaanse taalbewegings in te gaan. Onder taalaktivisme word aksies verstaan waarmee lede van 'n taalgemeenskap druk op politieke, ekonomiese en ander maghebbers probeer uitoefen om ongewenste taalbeleide en taalpraktyke te verander. Sulke aktiwiteite sluit die mobilisering van die gemeenskap, mediadekking van onder meer die resultate van ondersoeke, die vorming van drukgroepe, litigasie en selfs geweld in (Du Plessis 2004:170).

In hierdie artikel word die politieke strategieë behandel wat belangrike taalaktiviste tussen 1875 en 1925 gevolg het om amptelike status vir Afrikaans en gelyke regte met Engels te verwerf. Hier word op vyf historiese figure gelet, naamlik S.J. du Toit, genl. J.B.M. Hertzog, pres. M.T. Steyn, C.J. Langenhoven en J.H.H. de Waal. Hulle was nie die enigste leiers wat direk of indirek tot die vordering van Afrikaans bygedra het nie. Hulle optrede was egter deurslaggewend vir die bereiking van twee doelwitte, te wete die amptelike erkenning van Afrikaans en gelyke regte met Engels.

'n Paar woorde het sedert daardie tyd van betekenis of gevoelswaarde verander. Die opvallendste hiervan is volk. Dit het tans 'n ietwat ongunstige gevoelswaarde, weens die vroeëre misbruik daarvan deur politici. Die meeste outeurs verkies nou kultuurgemeenskap wanneer hulle na Afrikaners as 'n groep verwys.

Afrikaner het deur die eeue ook van betekenis verander. Du Toit, Steyn, De Waal en Langenhoven het Afrikaner gebruik met min of meer dieselfde betekenis as in die Handwoordeboek van die Afrikaans Taal (HAT) se 2015-uitgawe, naamlik '(veral wit) persoon (met 'n sterk gevoel van nasietrots) wie se moeder- of huistaal Afrikaans is' (Luther, Pheiffer \& Gouws 2015:30). Hertzog het soos sommige ander politici Afrikaner soms gebruik in die betekenis van wit mense wat 'n sterk gevoel van nasietrots en Afrikaans of Engels as huis- of moedertaal het. In ouer koerantberigte kom dus frases voor soos Engelssprekende en Afrikaans- of Hollandssprekende Afrikaners.

Hier is Hollandssprekend dus sinoniem met Afrikaanssprekend, want ook die benaming Hollands het in die negentiende en vroeë twintigste eeu in Suid-Afrika nie altyd 'Nederlands' beteken nie. 
Hollands het soms na Nederlands, soms na Afrikaans en Nederlands, en soms na Afrikaans verwys (Steyn 2014:107). Afrikaans dui in hierdie artikel steeds die Oosgrensvariëteit aan wat in hierdie tydperk gestandaardiseer is.

\section{S.J. du Toit}

S.J. du Toit het met sy taalaktivisme begin in 'n tyd van sterk weerstand teen die verwaarlosing van Hollands in die Kaapkolonie. Scholtz (1965:192) maak van die 'buitengewoon heftige verset' teen die toenemende verengelsing en die verdrukking van Hollands melding. Veral was daar fel aanvalle op die Engels-georiënteerde meisieskole wat deur die inisiatief van NG-predikante opgerig is.

Die direkte aanleiding tot Du Toit se optrede was egter die strewe na 'n Afrikaanse Bybelvertaling. Op 'n vergadering daaroor op 14 Augustus 1875 is die Genootskap van Regte Afrikaanders (GRA) gestig. Soos Du Toit dit gestel het, moes die gemeenskap eers oortuig word dat hulle 'n eie taal het. Hierdie taak was moeiliker as wat dit op die oog af gelyk het (Du Toit 1909:65). Dit was egter vir Du Toit nie genoeg nie. Vroeg verklaar hy: 'Afrikaans moet erken worde as Volkstaal, as offisiële taal' (Du Toit 1917:134).

Die woorde volkstaal en landstaal is vir die huidige leser problematies. Du Toit bedoel daarmee waarskynlik die taal van die hele Afrikaanse gemeenskap. Hy het in 1875 aan ds. George Morgan van die Britse en Buitelandse Bybelgenootskap geskryf dat die 'enigste maniir om di Afrikaans-sprekende bevolking, blanke en gekleurde, te beskawe, deur middel fan hulle Moedertaal moet geskide ...' (Du Toit 1909:64). Die land van landstaal het vir hom waarskynlik die Kaapkolonie wes van die destyds duidelik afgebakende Temboland, Fingoland en Brits-Kaffraria omvat. Soms het die land van landstaal vir hom ook die Vrystaat en Transvaal ingesluit.

Sy politieke strategie hiervoor het twee elemente behels: samewerking met die voorstanders van Hollands, asook ondersteuning van die Zuid-Afrikaansche Republiek (Transvaal) in sy vryheidstryd en vir 'n poging om van Afrikaans die offisiële taal van die republiek te maak.

\section{Politieke samewerking met mededingers}

Vanaf die stigting van die GRA en die verskyning van sy mondstuk, Die/Di Afrikaanse Patriot, in 1876 was dit duidelik dat Afrikaans en Hollands mededingers was. Tog het Du Toit 'n direkte stryd met kampvegters vir Hollands vermy en selfs hierdie taal help bevorder. Op 11 Mei 1877 skryf die Patriot:

Ons Genootskap is nie tegen die Hollanse taal nie, soos party van ons vyande geseg het; maar ons het die onmo'entlikheid ingesien om die Hollanse taal in ons land te herstel. (Du Toit 1917:148)

Sy standpunt oor samewerking stel hy duidelik in twee artikels oor die beskerming van die landstaal of volkstaal.

\footnotetext{
1 Die Patriot het Hollands konsekwent Hollans gespel. As gevolg van die onvastheid in die spelling word sommige woord verskillend gespel, selfs in dieselfde teks: soms byvoorbeeld di, soms die. Op sulke inkonsekwenthede gaan hier nie elke keer gewys word nie.
}

Hierdie beskerming was die belangrikste doelstelling van 'n Afrikanerbond, wat Du Toit in die Patriot bepleit het. Hy stel dit soos volg: 'Vernamelik ag hy sig geroepe di Volkstaal in beskerming te neem waar dit verwaarloos word op kerklik, maatskapliken staatkundig gebied, veral in di skole' (14 November 1879; Anon. 1882:9)

In 'n artikel op 21 November 1879 verklaar hy dat die beskerming van die 'Landstaal' die hoofsaak van so 'n bond moet wees. Of ons onder landstaal Afrikaans of Hollands moet verstaan, maak nie saak nie, sê hy. Die voorstanders van Afrikaans kan en sal vrywillig saamstem dat dit vir eers Hollands is omdat Afrikaans nog nie staatkundig erken is en geen literatuur, maar veral ook nog geen skoolboeke het nie. Bowendien is die behoud van Hollands terselfdertyd die bevordering van Afrikaans, want 'Hollans in Afrika is en word tog mar altyd Afrikaans' (Anon. 1882:9).

Hy wei uit oor die verskeie terreine waarop die volkstaal bevorder kan word: op kerklike, maatskaplike en staatkundige gebied. Wanneer hy laasgenoemde behandel, lewer Du Toit 'n historiese pleidooi vir gelyke taalregte deur die gebruik van politieke middele:

Ons doel moet wees gelyke reg ver Hollans en Engels. Dis net 'n kwessi van stemkrag, nix meer ni. As morge di bevolking by meerderheid van stemme uitspraak doen: 'ons wil dat Hollans in alle opsigte gelyke regte sal hê met Engels', dan moet dit geskiede, want ons het mos Verantwoordelike Bestuur. (Anon. 1882:10)

In die skole moet daar 'n einde kom aan Engels as die enigste voertaal.

Leer die kinders eers hul landstaal ken, dan kan hulle daarin alles leer. Dan sal hulle verstaan wat hulle leer en veel meer vordering maak. Albei tale moet ten minste gelykstaan, sodat die ouers kan kies in watter taal hul kinders geleer word. (Anon. 1882:10)

Du Toit het nog verskeie artikels oor ander aspekte van die beoogde party geskryf en hulle is in 1882 in 'n anonieme pamflet, Die Afrikanerbond, uitgegee. Toe was die eerste tak reeds gestig, maar die bond het veral van 1881 af veld gewen ná die oorwinning van die Transvalers oor die Britse mag by Majuba. In 1883 was daar 116 takke met 5800 lede in die Kolonie, 23 takke met 1273 lede in die Vrystaat en 13 met 923 lede in Transvaal. Die Afrikanerbond het in 1883 van karakter verander ná die samesmelting daarvan met die Zuid-Afrikaansche Boeren Beschermings Vereniging van J.H. ('Onze Jan') Hofmeyr.

Reeds voor die stigting van die Afrikanerbond het Du Toit met Hofmeyr saamgewerk om een van hulle albei se doelstellings te bereik. Dit was om Hollands as een van die tale in die Kaapse parlement te erken. Hulle twee en ander Afrikanerpolitici het deur middel van petisies druk op die Kaapse regering uitgeoefen. Die Patriot het voor 1882 talle petisies gedruk en teen groot koste uit sy kantoor versprei. Ná 'n mislukte poging in 1881 het die Kaapse parlement in 
1882 die gebruik van Hollands naas Engels as parlementêre taal erken. Hier het wins vir Hollands letterlik wins vir Afrikaans ingehou, want soos Von Wielligh (1922:91) vra: hoeveel parlementslede kon Hollands praat? Hulle het Afrikaans in die parlement gepraat. Hierna is nog enkele funksies vir Hollands gewen. Dit het egter nie beteken dat Hollands 'n amptelike taal geword het nie, konstateer Scholtz (1977:227).

Vir die onderwys het Du Toit 'n ander strategie gevolg wat eie aan taalaktivisme is. Dit is om self instellings te skep wanneer die staat onwillig is om dit te doen. Du Toit se projek was die oprigting van die Hugenote-gedenkskool op die plaas Kleinbosch in Daljosafat.

Du Toit het die skool in 1880 en 1881 in die Patriot bepleit en sy betoog op moderne argumente vir moedertaalonderwys gegrond. Hy skryf dat een van die kenmerke van die beoogde skool is dat dit "n Afrikaanse skool" moet wees waarin 'Hollans en Engels en alles wat tot 'n beskaafde opvoeding behoort grondig geleer word, mar in ons eie taal en vollens ons eie beginsels'. Die uitleg en verklaring van alles wat die kinders leer, moet vir hulle in Afrikaans gegee word sodat hulle verstaan wat hulle leer. Die onderwys deur medium van 'n vreemde taal verstomp die gees van die kinders; 'hulle word gewend om uit die hoof te leer sonder te verstaan, om na te praat sonder te denk' (Die Afrikaanse Patriot, 14 Januarie 1881). Die skool het op 01 Februarie 1882 begin en leerlinge gehad soos die skrywers D.F. Malherbe, J.D. du Toit (S.J. du Toit se seun, ook bekend as die digter Totius) en A.G. Visser.

Selfs buite die politieke gebied het Du Toit stryd vermy. Dit blyk uit die Patriot se kommentaar op die stigting van De Zuid-Afrikaansche Taalbond in 1890. By die stigting het die kongresgangers besluit dat Hollands en nie Afrikaans nie, die volkstaal is. Voor die stigting het die Patriot op 16 Oktober 1890 geskryf:

[A]l sou Hoog Hollans die leus wees, denk ons nog, ons sal kan saamwerk. Dit mog vreemd lyk, mar ons is o'ertuig, dat alles tog moet uitloop ten nutte van di Afrikaanse taal. (Du Toit 1917:162)

\section{Steun vir die Transvaalse vryheidstrewe}

Die Patriot het gewild geraak toe hy die kant van die Transvalers gekies het ná die anneksasie van Transvaal deur Engeland in 1877, asook die daaropvolgende Transvaalse Vryheidsoorlog (1880-1881). Sy oplaag het geleidelik gegroei: in 1879 was dit 1200, in 1880 1800, en van 1881 tot 1895 ongeveer 3000 (Du Toit 1909:176). Sy sirkulasie was in die vroeë jare van 1880 af groter as dié van die Hollandse koerante.

Ná die Transvaalse Vryheidsoorlog het een van die vroeë skrywers, Jan Lion Cachet, by Paul Kruger daarop aangedring om Afrikaans as die offisiële taal van hierdie republiek te erken. Cachet het Kruger verseker dat hy 'Transvaal als vrije republiek sou behou als Afrikaans offisiële taal erken werd, terwijl hij Transvaal sou verlies als dit nie gedaan word nie' (Du Toit 1917:136). Wat sy argumente was, is ongelukkig onbekend.

Dit is onseker of Du Toit na Cachet of na 'n ander persoon en 'n ander geleentheid verwys wanneer hy meld dat een van die prominente lede van die GRA in 1881 met die republikeinse leiers, die sogenaamde Driemanskap (Paul Kruger, M.W. Pretorius en Piet Joubert), oor Afrikaans as offisiële taal gepraat het. Hulle was eenparig daarvoor, maar wou hê dat die volk dit vra. Op kmdt. J.H. Fouché se plaas Olifantshoek naby Rustenburg, het die GRA-lid 'n taamlike groot byeenkoms toegespreek. Hy het die mense vertel wat die Driemanskap dink, en hulle aangeraai om petisies vir Afrikaans te teken. Die vergadering was eenparig vir Afrikaans (Du Toit 1917:112). Hiervan het egter niks gekom nie.

Tot voor die ontdekking van goud in 1886 en die toestroming van duisende uitlanders na die goudveld is algemeen aanvaar dat die taal van Transvaal Hollands is. Die koms van soveel vreemdelinge in ' $n$ kort tyd het kommer oor die landstaal laat ontstaan. Om die Afrikanerkarakter van die staat te behou, is Hollands erken. Wet 10 van 1888 bepaal: 'De Hollandsche taal is de officieele taal des lands. Alle andere talen zijn vreemde talen' (Scholtz 1977:459).

Du Toit was sedert 1882 superintendent van onderwys in diens van die ZAR, maar hy het geen poging aangewend om Afrikaans die amptelike taal te maak nie. Aangesien Hollands die onderwystaal van Transvaal was, was hy direk met die bevordering van dié taal gemoeid en dus nie van Afrikaans nie.

Dit lyk derhalwe of Du Toit in sy Transvaalse tyd sy strewe laat vaar het om van Afrikaans 'n offisiële taal te maak, miskien ook omdat hy besef het dat die republiek se beleid die Transvaalse Afrikaners nie in die praktyk benadeel het nie. Ná Du Toit se terugkeer na die Kaapkolonie is hy uit sy ou party, die Afrikanerbond, uitgewerk. In 1898 het hy 'n nuwe party, die Koloniale Unie, gestig wat Engels en Hollands as amptelike tale wou hê.

Tog het Afrikaans as amptelike taal nie heeltemal uit sy strewe verdwyn nie. Op die Paarlse taalkongres van 1897 waarvan Du Toit die groot dryfkrag was, is die oorspronklike oogmerke van Du Toit herbevestig. Die slotgedeelte van 'n besluit lui 'dat Afrikaans behoor erken en beoefen te worde as skryftaal, en selfs as offisi'ele taal, op staatkundige sowel as maatskappelike gebiid, insonderhyd op di skole' (Steyn 2014:38).

\section{Generaal J.B.M. Hertzog en president M.T. Steyn}

Ná die Anglo-Boereoorlog (1899-1902) was Engels die enigste offisiële taal in al die Britse kolonies, dus ook die gewese republieke waarin Hollands voor die oorlog nog die amptelike taal was. Die politieke leiding in hierdie twee kolonies is deur die gewese Boeregeneraals geneem, naamlik Louis Botha en 
Jan Smuts in die Transvaal-kolonie en J.B.M. (Barry) Hertzog en later ook pres. M.T. Steyn in die Oranjerivier-kolonie ([ORK] - die Vrystaat). Hulle het na die herstel van Hollands as onderwys- en amptelike taal gestreef. Hulle grootste suksesse was die oprigting en heroprigting van 'n paar Hollandse koerante en die stigting van skole wat Hollands as een van hulle voertale gebruik het.

Nadat Smuts met sir Henry Campbell-Bannerman, Britse Eerste Minister, beraadslaag het, het die kabinet besluit om selfregering aan die twee gewese republiek toe te staan (Giliomee 2004:225). 'n Volgende stap was unifikasie. Op die interkoloniale spoorweg- en doeanekonferensie in Mei 1908 in Pretoria is 'n voorstel van Smuts aanvaar om 'n nasionale konvensie te hou wat die staatkundige vereniging van Transvaal, die Kaapkolonie, die ORK en Natal kon bespreek. Die eerste sitting van die Nasionale Konvensie is van 12 Oktober tot 05 November 1908 in Durban gehou, die tweede van 23 November 1908 tot 03 Februarie 1909 in Kaapstad en die derde van 05 tot 11 Mei 1909 in Bloemfontein. Sir Henry de Villiers, hoofregter van die Kaapkolonie, was voorsitter en pres. Steyn ondervoorsitter.

Vir die onderhandelaars was taal 'n groot kwessie. Dit was vir die Engelssprekende leiers en meningsvormers vanselfsprekend dat Engels die enigste amptelike taal moes bly: die nuwe magsverhoudings noodsaak dit, is betoog. Bowendien was daar twyfel of Afrikaans sal kan voortbestaan - en indien 'n taal gaan uitsterf, behoort dit nie kunsmatig deur wette aan die lewe gehou te word nie. Engels is die taal van beskawing en geleerdheid, die 'superior' taal, en dié moet gekies word. Ten slotte is betoog dat ware eenheid amptelike eentaligheid noodsaak. Die Natal Mercury het op 20 Maart 1909 geskryf: 'There can be no true union, the nation will never become one, which speaks with two voices' (Steyn 2014:104).

Dit het gelyk asof die Transvaalse leiers nie so sterk oor gelyke regte voel nie. Nadat die gewese republieke selfregering gekry het en dus seggenskap oor onderwys, het die Transvaalse onderwyswet van Smuts groter gewig aan Engels as aan Hollands toegeken. Vir die eerste vier skooljare was Hollands wel die medium vir Afrikaanssprekendes, maar waar die moedertaal nie Engels was nie, moes Engels geleidelik ingevoer word totdat dit teen graad 6 die voertaal sou wees, met die uitsondering van twee vakke wat nog in Hollands gedoseer kon word. In 1905 het Smuts aan 'n Australiese joernalis gesê dat Engels die offisiële taal van Suid-Afrika sou wees en Hollands 'toegelaat' sou word (Giliomee 2004:226).

Hertzog en Steyn se oogmerk was die amptelike status vir Hollands, maar veral gelyke behandeling van Hollands en Engels. Sonder laasgenoemde kon hierdie status maklik vervlak het tot 'n amptelike status slegs in naam. Hertzog en Steyn se strategie was ten eerste om druk op ander leiers uit te oefen om gelyke regte te verseker, met die wete dat unifikasie moeilik sou kon voortgaan indien die geografies sentrale kolonie sy samewerking sou weier. Ten tweede kon hulle, sonder om enigiemand te probeer mislei, die destyds gangbare meerduidige benaming Hollands of Dutch benut en het so die uiteindelike erkenning van Afrikaans makliker gemaak.

\section{Gelyke regte aan Hollands en Engels}

Hertzog het gereeld die kwessie van gelyke taalregte in die debat oor unifikasie geopper. In een van 'n aantal toesprake van 1907 sê hy dat die heropbou van die Afrikaner net so belangrik as unifikasie is. As unifikasie nie daartoe 'n bydrae lewer nie, is dit nie die moeite werd nie. Daarom moet die Afrikaner sy selfrespek herwin, want daarsonder kan hy nie respek van ander verwag nie. Vir hierdie selfrespek is die gelykheid van Afrikaners en Engelse nodig (Spies, Krüger \& Oberholster 1977:109).

Hy en pres. Steyn was net bereid om tot unifikasie in te stem indien Hollands ' $n$ amptelike taal sou word en gelyke behandeling met Engels sou geniet. Voor die Konvensie het Steyn sy standpunt hieroor aan verskeie openbare figure gestel. Dit blyk uit briewe wat opgeneem is in die boek van De Wet, Van Heyningen en Van der Merwe (2017).

Vroeg in Junie 1908 skryf Steyn aan J.H. ('Onze Jan') Hofmeyr dat onder andere John X. Merriman, Eerste Minister van die Kaapkolonie, en Hertzog sterk voel dat hy (Steyn) die konvensie moet bywoon. Hertzog was van mening dat dit beter is om op die konvensie te stry vir sake waaroor hulle sterk voel, as om later die verantwoordelikheid te moet neem om die aanname van die grondwet af te raai. Hierdie argument weeg swaar by hom, skryf Steyn. Hy haal aan wat hy op 08 Junie 1908 aan Merriman geskryf het, naamlik dat hy nie tot 'n konstitusie sou toestem as die gelykstelling van die 'rassen' (Afrikaners en Engelssprekendes) nie daarin vasgelê is nie. Hy begryp dat hy vir gelyke taalregte met die opposisie te kampe sal hê. Tot 'n stryd met hulle is hy wel bereid, maar hy is nie bereid om met 'mannen uit onze party te stryden' (De Wet et al. 2017:154, 155). Met 'onze partij' bedoel hy die Afrikanergeoriënteerde partye in die kolonies wat later verenig sou word. Hy wou nie graag met genls. Botha en Smuts en ander Afrikanerleiers op die konvensie oor taal baklei nie.

Laat in Junie 1908 het Botha, Eerste Minister van Transvaal, Steyn op sy plaas Onze Rust naby Bloemfontein besoek en gepleit om die Konvensie by te woon. Botha skryf aan Merriman oor Steyn se houding:

His great difficulty is with reference to the Dutch Language, and he has objection to going on the Convention unless we are in earnest as regards the absolute equality of both languages. I gave him my assurance on this point. (Thompson 1960:137)

Thompson (1960) meen tereg dat Steyn op hierdie wyse 'n belangrike eerste ronde vir die standpunt van die Orangia-Unie (die Afrikaner-georiënteerde party van die ORK) gewen het.

Although there remains underlying differences of opinion to the full implication of the phrase 'the absolute equality of both languages', 
Botha could hardly fail to support any proposal for a section providing for language equality emanating from Hertzog and Steyn. (p. 138)

Op 03 September 1908 reageer Steyn op 'n Suggested Scheme for South African Union wat opgestel is deur Smuts. Onder die opskrif Use of English and Dutch languages skryf Smuts:

Either the English or the Dutch language may be used by any person in the debates of the Houses of Parliament; and both languages shall be used in the respective record and journals of those Houses, and either of those languages may be used by any person. Or in any pleading or process in or issuing from the Supreme Court of South Africa or the High Courts and District Courts for the Provinces. The Acts of the Parliament shall be printed and published in both those languages. (Hancock \& Van der Poel 1966:487)

Steyn antwoord Smuts dat hy hom grootliks met sy plan kan vereenselwig. Met een aspek daarvan gaan hy egter nie akkoord nie en dit is die taal. Hy meen daar moet nie alleen gelyke regte in die howe en die parlement wees nie, maar ook in die skole en die staatsdiens. Met ander woorde, Hollands moet soos Engels 'n offisiële taal wees. Hy sal nie vrywillig sy eie groep ondergeskik maak aan die ander groep nie. Slegs gelykheid sal ware vereniging bring. 'De taal is voor my een van de kardinale punten' (De Wet et al. 2017:163).

\section{Onderhandelings oor taal op die Nasionale Konvensie}

Die eerste belangrike vraagstuk wat die Nasionale Konvensie op sy sitting in Oktober 1908 in Durban moes bespreek, was die vraag of die nuwe staat ' $n$ unie of ' $n$ federasie moes wees. Natal het vir 'n federasie gepleit, maar het naderhand toegegee, omdat die provinsies die mag sou kry oor laer en middelbare onderwys, munisipale sake, hospitale en paaie.

Die volgende saak op die agenda was taal. Daar was onder die konvensiegangers verskillende menings oor wat die taalgelykheid moet behels. Twee konsepvoorstelle het nie ver genoeg vir Hertzog en Steyn gegaan nie. Die eerste was dié van Smuts. Steyn se brief aan hom het hom klaarblyklik oor een punt oortuig, naamlik dat Hollands ook amptelike status moet geniet. In 'n konsep aan die Transvaalse afgevaardigdes het hy voorgestel: 'Both the English and Dutch languages shall be official languages of the Union and may be employed in the Parliament and its proceedings and also in the Courts of Law' (Thompson 1960:192). Maar wat beteken die frase 'official language'? Dit het geen presiese wetlike betekenis gehad nie. Merriman se konsep het prakties neergekom op 'n voortsetting van die negentiende-eeuse beleid van die Kaapkolonie wat Hollands in die parlement en in laer geregshowe toegelaat het sonder om dit as amptelike taal te erken. Merriman se konsep het gelui:

Either the English or the Dutch language may be used by any person in the debates of the Houses of Parliament of the Union, and both these languages shall as Parliament may deem fit be used in the respective records and journals of the House, and either language may by used by any person in any pleadings or proceedings in any court of the Union. (Thompson 1960:192)
Vier ORK-afgevaardigdes, Hertzog, Steyn, Abraham Fischer en genl. C.R. de Wet, het baie sterk oor die taalkwessie gevoel. Die ander Vrystaatse afgevaardigde, die Brits-gebore Albert Browne, was lid van die party wat gekant was teen Hertzog se onderwyswet. 'n Konsep wat Hertzog op pad na Durban in die trein geformuleer en deur sy sekretaris laat tik het, is deur die ander drie Vrystaters gesteun (Nienaber 1952:65; Van den Heever 1944:267). Die voorstel het gelui:

That in order to effect a closer Union of the Colonies represented at the Convention, and in order fully to attain the object of its establishment, it is essential that both English and Dutch be recognized as the National and Official language of the Union; to be treated on a footing of equality and to possess and enjoy equal freedoms, rights and privileges in all the various offices, functions and services of whatsoever kind or nature administered by and under the Union; and that every appointment under the Union shall be made with a due regard to the equality of the two languages and to the right of every citizen of the Union to avail himself and to claim either language as the medium of communication between himself and any officer or servant of the Union; and that all the records, journals and proceedings of the Union Legislature, as likewise all Bills and Laws of the Union, and all official notifications of general public importance or interest published in the Gazette, or otherwise, shall be issued and published in both the English and Dutch languages. (Spies et al. 1977:226; Thompson 1960:193)

Die konsep is onder die afgevaardigdes versprei. Sommige Afrikaners was 'skugter en terughoudend' hieroor, aldus C.M. van den Heever (Hertzog se biograaf) en onwillig om dit te steun tensy die Engelse lede daarvoor te vinde was. Hertzog het hulle dit baie kwalik geneem. Taalgelykheid was vir hom die hoeksteen van unifikasie (Van den Heever 1944:267).

Die meeste Engelssprekende afgevaardigdes wat die mosie gelees het, was volgens Thompson (1960:194) 'appalled by it'. Vir hulle was dit reeds 'n groot toegewing as hulle 'n mosie soos dié van Smuts sou steun. Hertzog s'n het onmoontlik gelyk omdat die geïmpliseerde dwang vir hulle soos die ORK-onderwyswet gelyk het. Hierdie wet het tot verset by Engelssprekendes gelei. Hertzog se onderwyswet van 1908 het Engels en Hollands op gelyke voet geplaas. Dit het bepaal dat leerlinge van Standerd 5 (Graad 7) af deur medium van sowel Engels as Hollands onderwys sou ontvang. Tot in matriek moes drie vakke in Engels en drie vakke in Hollands gegee word. Engelssprekendes het nie die verpligte Engels aan Afrikaanse kinders as dwang beskou nie, maar wel die verpligte Hollands vir Engelse kinders.

J.W.Sauer, een van die Kaapse afgevaardigdes, het L.S. Jameson en sir Percy Fitzpatrick die middag van 15 Oktober meegedeel dat Steyn en Hertzog wou uitstap indien die Hertzog-mosie nie aanvaar word nie. Jameson en Fitzpatrick se antwoord was dat 'n ultimatum vir hulle onaanvaarbaar was (Thompson 1960:194). Hertzog was inderdaad volgens Van den Heever (1944:267) van plan om hom aan die Konvensie te onttrek as sy voorstel misluk, selfs onmiddellik.

'n Uur of wat ná Sauer se mededeling was een van die sake op die agenda afgehandel en het die voorsitter, 
sir Henry de Villiers, onbewus van die dreigende botsing, die volgende saak aan die orde gestel. Hertzog het die taalkwessie geopper. Fitzpatrick het ná haastige oorleg met Jameson na Hertzog se stoel geloop en hom gevra om die verdaging van die debat voor te stel. 'n Onmiddellike debat sou moeilikheid kon veroorsaak. Indien hulle die saak informeel kon bespreek, kon hulle 'n aanvaarbare skikking bereik. Ná 'n bietjie huiwering het Hertzog 'n verdaging voorgestel (Thompson 1960:194).

In die informele gesprekke oor die taalklousule het verskeie Engelssprekendes beswaar gemaak teen die element van dwang in die volgende woorde in sy voorstel:

\begin{abstract}
... and that every appointment under the Union shall be made with a due regard to the equality of the two languages and to the right of every citizen of the Union to avail himself and to claim either language as the medium of communication between himself and any officer or servant of the Union. (Thompson 1960:195)
\end{abstract}

Hertzog het die beswaarmakers tegemoetgekom en hierdie woorde uit sy voorstel weggelaat. Ook die woord national and in die frase national and official language het verval. Die gewysigde voorstel het Hertzog op 16 Oktober ingedien (Thompson 1960:195). Op 16 Oktober het Hertzog kennis gegee van die mosie.

Op die dag van die taaldebat, Maandag 19 Oktober, is 'n telegram van die Taalbond voorgelees wat deur J.H. Hofmeyr opgestel is. Daarin is gelyke regte vir die twee tale gevra in die 'Legislatures, the courts of law, the Civil Service and the educational establishment of a Federated or Unified South Africa' (De Villiers 1936:249).

Hertzog het sy mosie gestel, wat eintlik 'n amendement was op dié van Smuts, wat niks oor gelyke behandeling of tweetaligheid bevat het nie (Le Roux, Coetzee \& Marais 1987:97). Hertzog het volgens F.S. Malan met erns en gevoel, maar tog gematig gepraat. Hy het gesê dat hy slegs grondbeginsels wou neerlê, maar dit aan die Unieregering sou laat om dit met billikheid toe te pas (Preller 1951:38-40).

Ná Hertzog het pres. Steyn in Engels gepraat. Al sy toesprake op die konvensie het hy in Hollands gehou, maar besluit om sy toespraak oor die taalkwessie in Engels te lewer, sodat daar by geen afgevaardigde enige misverstand kon wees oor wat hy oor taalgelykheid wou verklaar nie.

Giliomee (2004) noem pres. Steyn se toetrede tot die debat die 'mees dramatiese oomblik by die konvensie'. Hy het gesê dat Hollands op een of ander tydstip die ampstaal van al die kolonies was:

Ons taal het sy offisiële karakter alleen deur geweld verloor. Vir geweld moes ons swig. Die Konstitusie wat ons nou gaan opstel, sal ons eie daad wees, en niemand kan verwag dat ons vanself ons taal en ons volk in 'n onderdanige posisie sal gaan plaas nie. As ons dit sou doen, sal die volk nimmer sy goedkeuring daaraan heg nie, en in plaas van vereniging sal ons Suid-Afrika nog meer verdeel. (Van der Merwe 1921:289)
Die gelykheid van die tale is die simbool van die gelykheid van die volksgroepe, het hy gesê (Van der Merwe 1921: 288-289).

Hy het so gevoelvol oor die versoening tussen die twee taalgroepe gepraat dat dit die afgevaardigdes geroer het en die oë van meer as een betraand was, volgens F.S. Malan, 'n Kaapse afgevaardigde. Hy meld in sy dagboek dat hy herhaaldelik sy trane moes afvee (Preller 1951:40). Geen ander leier het destyds soveel aansien in Suid-Afrika geniet as pres. Steyn nie. Meer as een het hom die 'ongekroonde koning' van die land genoem. Wat tot die ontroering op die konvensie bygedra het, was waarskynlik die bewustheid van alles wat hy in die oorlog deurgemaak het.

Ná sy toespraak het niemand die beginsel van taalgelykheid teengestaan nie. Jameson het toegegee dat hy en ander die saak in die verlede nie reg begryp het nie en dat dit nodig was om 'n nuwe blaadjie om te slaan. Hy wou egter geen 'dwang' in verband met die taal uitoefen nie en juig dit toe wat Hertzog gesê het, naamlik dat by die aanstelling van amptenare rekening gehou moet word met die taal van die bevolking wat hulle gaan dien. Hy was van mening dat dit ingesluit moes word in die voorstel (Preller 1951:40). Ook Merriman het die beginsel van taalgelykheid ondersteun, maar gepleit dat niemand tot tweetaligheid gedwing moes word nie.

Ná afloop van die middag se sitting het 'n kommissie die bewoording van die voorstel verder bespreek. Thompson (1960:197) noem onder andere Hertzog, Malan, sir George Farrar en Fitzpatrick as lede van die kommissie. Hulle het gesorg vir 'n eenvoudiger bewoording.

Die mosie is op 20 Oktober om taktiese redes nie deur Hertzog nie, maar deur Farrar ingedien:

Both the English and Dutch languages shall be official languages of the Union, and shall be treated on a footing of equality, and shall possess and enjoy equal freedoms, rights and privileges; all records, journals and proceedings of Parliament shall be kept in both languages, and all Bills, Acts, and notices of general public importance and interest issued by the Government of the Union shall be in both languages. (Thompson 1960:197)

Hierdie mosie is met toejuiging aanvaar. Ná al die spannende onderhandelings was die aanvaarding van die mosie vir Hertzog 'n persoonlike triomf; dit was vir hom 'n ontroerende oomblik', sê Van den Heever (1944:268). Opgetoë skryf Hertzog onder die opskrif: 'Groote ovewinning':

10.27 deze morgen - besluit algemeen aangenomen verklaarde beide de Hollandsche en Engelsche taal als de officieele talen der Unie te worden behandeld op gelijke voet en te genieten gelijke vrijheden, rechten en voorrechten enz. 20 Oct. 1908. Daaronder plaas hy weer eens die tydstip en sy handtekening. (Spies et al. 1977:227)

Om Merriman en ander Engelssprekendes tegemoet te kom - hulle was bevrees vir dwang teenoor eentalige amptenare - is ook 'n mosie aangeneem wat as artikel 145 
van die grondwet aanvaar is. Die Nederlandse bewoording daarvan lui: 'Ambtenaren in dienst van een Kolonie ten tijde van de totstandkoming van de Unie worden niet ontslagen uit hoofde van hun onbekendheid met of de engelse of de hollandse talen'.

\section{Die betekenis van 'Hollands'}

Dit val op dat Afrikaans en die ander inheemse tale nie 'n onderwerp van die debat was nie. Baie kiesers, miskien die meerderheid, was Afrikaans (in die Kaapkolonie het ook bruin kiesers stemreg gehad), terwyl Xhosa die taal van sommige kiesers van die Kaapkolonie was. De Waal (1939:282) sê dat hoewel Hertzog lid was van die Afrikaanse Taalgenootskap soos trouens ook Botha en Smuts, hy in sy toesprake Nederlands of Engels gebruik het. Nie Hertzog, Smuts, Botha, Frans Malan, 'Onze Jan' Hofmeyr of Steyn het 'daaraan gedroom om Afrikaans as tweede amptelike taal van die Unie, selfs as opsioneel', voor te stel nie. En 'n mens sou kon byvoeg: nie hulle en ook nie Merriman, Jameson, Farrar of Fitzpatrick het kon droom dat Xhosa en ander inheemse tale moontlik ook amptelike tale kon wees nie.

Die taalbepaling is op 20 September 1909 vasgelê in die 'South Africa Act/An Act to constitute the Union of South Africa', 'n wet van die Britse parlement. Artikel 137 lui dat 'both the English and Dutch languages' amptelike tale is. Maar moes Dutch nou vertaal word met Hollands of Nederlands?

De Waal (1939:282) sê dat Hertzog tipies soos die ander volksleiers opgetree het: hy was 'vir Hollands - Nederlands en Afrikaans'. Die leiers se steun vir Afrikaans het nie beteken dat hulle Nederlands deur Afrikaans wou laat vervang nie, maar dat hulle simpatiek teenoor die Afrikaanse beweging gestaan het en dit nie sou teëwerk nie. Volgens De Waal is die versekering aan hom gegee dat die keuse van die 'vorm van Hollands' (Afrikaans of Nederlands) aan Afrikaanssprekendes oorgelaat is (De Waal 1939:283).

Miskien verwys hy hier na die besprekings op 'n vergadering van taal- en politieke leiers op 05 Januarie 1909 in Kaapstad, waar die Nasionale Konvensie toe sittings gehou het. Hierdie vergadering is volgens De Villiers (1936:248) 'op 'n wenk van' Steyn, Hertzog en Hofmeyr belê. Die voorstanders van Afrikaans in die verskillende state is ook na 'n konferensie vir alle belangstellendes in die Hollandse taal uitgenooi. Sewentien Afrikaners was in die Hugenote-gebou in Victoriastraat, Kaapstad, teenwoordig. Onder hulle was voorstanders van Afrikaans soos Willie Hofmeyr, D.F. Malan en Jannie de Waal, asook vegters vir Nederlands soos Adriaan Moorrees, W.J. Viljoen, Frans Malan en Gawie Cillié.

Die betekenis van die benaming Hollands is deeglik uitgepluis. Hertzog het in 1925 in die Volksraad die volgende daaroor gesê: 'Ons het daar die kwessie van die woord Hollands bespreek en daar is ooreengekom dat Hollands is die regte term om te gebruik omdat daaronder sowel Afrikaans as Nederlands verstaan word'. Die benaming Hollands in artikel 137 van die 'Zuid-Afrika Wet' het dus op sowel Nederlands as Afrikaans betrekking (Anon. 1925:kolom 78-79).
Hertzog se voorstel vir die stigting van 'n liggaam 'ter bevordering van die Hollandse taal' is aanvaar nadat ' $n$ amendement van J.H. Hofmeyr, gesteun deur De Waal, verwerp is. Dit het gelui dat ook kennis geneem word van albei rigtings en taalgenootskappe in Suid-Afrika. Ons Land het op 19 Januarie 1909 opgemerk dat selfs die meeste lede van die Afrikaanse Taalvereniging die amendement as onnodig beskou het omdat onder 'Hollandse taal' ook Afrikaans inbegrepe is (De Villiers 1936:249).

Hierdie liggaam vir die bevordering van Hollands was die Zuid-Afrikaanse Akademie voor Taal, Letteren en Kunst, wat op 02 Junie 1909 in Bloemfontein gestig is. Volgens sy statute is die doel van die Akademie die handhawing en bevordering van die Hollandse taal en lettere. Verder word gespesifiseer: 'Onder het woord "hollandse" wordt verstaan de beide taalvormen gebruikelik in Zuidafrika' (De Villiers 1936:278).

Sonder die erkenning van Hollands in 'beide taalvormen' sou dit veel moeiliker gewees het om Afrikaans as amptelike taal te erken.

\section{C.J. Langenhoven en J.H.H. de Waal}

Twee taalaktiviste, Langenhoven en De Waal, het die voorlaaste belangrike stappe vir die erkenning van Afrikaans gedoen. Daar is merkwaardige ooreenkomste tussen die twee. Hulle was albei redakteurs wat hulle posisie gebruik het om Afrikaans te bevorder; albei was skrywers en regsgeleerdes, en albei het as politici 'n mate van amptelike erkenning bewerkstellig.

De Waal het al in die negentiende eeu Afrikaanse toneelstukkies geskryf en rympies in ligte trant in Ons Land gepubliseer. Sy oom, 'Onze Jan' Hofmeyr, het hom in 1903 oorreed om redakteur van De Goede Hoop te word. De Goede Hoop is op die been gebring deur Kaapse yweraars vir Nederlands as die skryftaal vir Afrikaanssprekendes. De Waal het egter van die begin af Afrikaans toegelaat en self bydraes in Afrikaans geskryf - en die tydskrif as 't ware vir Afrikaans 'gekaap', in die hedendaagse spraakgebruik.

Langenhoven was aanvanklik nie vir enige liefde vir Hollands of Afrikaans bekend nie. In 1893 het hy as eerstejaarstudent op Stellenbosch vir Engels gepleit, neerhalend verwys na Afrikaans en smalend gepraat oor die GRA en veral sy 'ringleader', S.J. du Toit (De Villiers 1936:154). De Waal (1939:288) onthou hoe skerp Langenhoven hom by hulle eerste kennismaking op Oudtshoorn 'aangepak het oor my malle ywer vir die armsalige Kaapse Hollands'. Dit is eers na die stigting van De Waal se Afrikaanse Taalvereniging aan die einde van 1906 dat Langenhoven tot Afrikaans bekeer is. In 1912 het hy redakteur van Het Zuid-Westen geword en van toe af het die land 'weergalm van Afrikaans-propagandakrete soos nooit tevore gehoor is nie' (Langenhoven 1956:319).

Terwyl Hollands vir die ander taalaktiviste onontbeerlik was in die stryd teen verswelging deur Engels, was dit Langenhoven en in 'n mindere mate De Waal se strategie om 
Hollands, in die betekenis van 'Nederlands', openlik te beveg en deur Afrikaans te laat vervang. In sy herinnerings verklaar Langenhoven dat ' $n$ groot deel van sy stryd nie teen Engels was nie, maar teen Nederlands (1956:314). De Waal het weer in 1905 'n lang polemiek met W.J. Viljoen, die vernaamste propageerder van die Vereenvoudigde Hollandse spelling gevoer.

Langenhoven het in 1910 sterk teen Hertzog se onderwyswet te velde getrek omdat dit leerlinge van die huidige Graad 7 af sou dwing om deur medium van sowel Engels as Hollands onderwys te ontvang. Kritiek op hierdie wet het ' $n$ kettingreaksie aan die gang gesit wat Langenhoven in staat gestel het om Nederlands deur Afrikaans te vervang. In die Volksraad het kol. C.P. Crewe van Oos-Londen, 'n lid van die opposisieparty die Unioniste, in November 1910 'n skerp aanval op Hertzog se onderwyswet gedoen. Fitzpatrick het gesê dat artikel 137 nie die verpligte gebruik van die twee tale beteken nie, anders sou die Engelssprekendes nooit in 1908 ingestem het tot artikel 137 nie. Op voorstel van die Eerste Minister, generaal Botha, is die taalkwessie in die onderwys na 'n gekose komitee verwys. In 'n meerderheidsverslag is aanbeveel dat die kinders tot in die Standerd 4 (tans Graad 6) in hulle moedertaal onderrig moes ontvang Daarna kon die tweede taal ook as medium van onderrig gebruik word (Cilliers 1953:172-182; Scholtz 1979:153-155). Die onderwystaal was 'n aangeleentheid waaroor provinsiale rade moes besluit. Transvaal het derhalwe in 1911 en die Vrystaat en Kaapland in 1912 ordonnansies aangeneem wat bepaal het dat die huistaal tot en met Standerd 4 (Graad 6) die verpligte voertaal sou wees, hoewel die ander amptelike taal as voertaal ingevoer kon word waar die ouers dit verlang.

Die moedertaal was vir Afrikaners amptelik nog 'Hollands', en die skole het dit oor die algemeen as Nederlands geïnterpreteer. Daaraan wou Langenhoven 'n verandering bring. Hy het hom vir die provinsiale raad verkiesbaar gestel en is onbestrede vir Oudtshoorn verkies. Toe Langenhoven vir sy eerste sitting in die Kaap aankom, het hy met die voormanne van die Afrikaanse beweging gaan praat oor sy plan om Afrikaans as onderrigmedium vir Afrikaanse kinders te laat erken. Hulle het hom aangeraai om eers te wag totdat Afrikaans verder in die pers en letterkunde gevorder het. Hy het hulle raad geïgnoreer en die politici bearbei. Eers het hy die lede van sy eie Suid-Afrikaanse Party oorgehaal. Toe het hy met die administrateur, sir Frederic de Waal, en superintendent-generaal van onderwys, Thomas Muir, gepraat en ten slotte die koukus van die Unioniste toegespreek.

Hy het sy voorstel op 23 April 1914 gedoen, naamlik dat Afrikaans-Hollands as medium gebruik word waar Hollands volgens die wet die voertaal is. Dit is ná 'n paar toesprake onbestrede aangeneem. Met die vreemde benaming AfrikaansHollands het Langenhoven Afrikaans bedoel. Hy het 'Hoog-Hollands' Nederlands-Hollands genoem (Langenhoven 1956:314). Die Vrystaat en Transvaal het op 15 Junie en 23 Junie 1914 dieselfde besluit. Natal het in 1916 'n ordonnansie aangeneem wat ouers in Natal die reg gegee het om tussen Afrikaans of Engels as voertaal te kies.

Hierdie provinsiale besluite was 'n belangrike stap op die pad na amptelike erkenning. Dit was die eerste keer dat daar in wetgewing bepaal is dat Hollands Afrikaans insluit, of selfs 'Afrikaans' beteken. Tweedens het Langenhoven hierdie besluite vernuftig gebruik om die Akademie oor te haal om Afrikaanse spelreëls te laat opstel en sodoende die standaardisering van Afrikaans bespoedig. 'n Regering sou 'n standaardtaal makliker erken as 'n taal wat nog nie ten volle gestandaardiseer was nie. Christo van Rensburg (2017) gee 'n meesterlike beskrywing van die strategie wat Langenhoven by die Akademie se sitting van 1914 gevolg het.

Dit was nogtans moeilik om die politici te oorreed om Afrikaans vir amptelike doeleindes te gebruik. Die eerste stap in die Volksraad is deur De Waal gedoen. Hy is in 1915 as lid van die Nasionale Party vir die kiesafdeling Piketberg verkies. In 1918 het hy 'n poging aangewend om van Afrikaans 'n amptelike taal vir administratiewe doeleindes te maak.

Sy poging op 19 Maart 1918 was 'n mosie tydens die bespreking van die wetsontwerp op die staatsdienskommissie in die Volksraad. Hy het voorgestel dat 'Afrikaans vir die staatsadministrasie ingesluit sal word by Hollands as een van die amptelike tale van die Unie' (De Volkstem, 22 Maart 1918). 'n Amendement van N.J.de Wet, minister van justisie, is aangeneem:

Hierdie Huis beskou dat Afrikaans ingesluit word onder Hollands as een van die offisiële tale van die Unie en dat hierdie beginsel erken behoort te word vir alle staats- en offisiële doeleindes, behalwe in gevalle van wetsontwerpe en wette van die parlement, en van offisiële dokumente vir een van die beide Huise van die Parlement, in welke geval slegs die vereenvoudigde vorm van Hollands gebesig sal word. (De Volkstem, 02 April 1918; Steyn 2014:206)

Afrikaans was hiervolgens die amptelike taal buite die parlement, maar nie binne die parlement nie. Oor die geldigheid van die Volksraadsbesluit het daar buitendien twyfel ontstaan na kritiek deur 'n regsgeleerde, Melius de Villiers (Steyn 2014:206).

Hierdie twyfel is uit die weg geruim op 'n gesamentlike sitting van die Volksraad en die Senaat op 08 Mei 1925. Dit is deur die aanstelling van 'n gezamenlike komitee op het gebruik van Afrikaans in wetsontwerpen, wetten en officiële dokumenten van het Parlement voorafgegaan ná 'n voorstel van Dr. D.F. Malan, Minister van Binnelandse Sake, Onderwys en Volksgesondheid, op 18 Februarie 1925 in die Volksraad. In die debat het Hertzog, toe Eerste Minister, oor die betekenis van die benaming Hollands uitgewei. Hy het gesê dat hy in 1908 met opset die woord Hollands gebruik het en nie Nederlands nie. Die helfte van die wit bevolking is 'Hollandssprekendes', maar ons bedoel nie hulle praat Nederlands nie. 'As ons Nederlands meen, dan praat ons van 
Hoog-Hollands. Hollands is die geykte term. [...] Hollands as taal van Suid-Afrika beteken Afrikaans en niks anders nie'. Hertzog het toe na die vergadering van 05 Januarie 1909 verwys waarop ooreengekom is dat Hollands die regte term is om te gebruik, omdat daaronder sowel Afrikaans as Nederlands verstaan word. Hollandssprekendes het HoogHollands geskryf en dit ook geleer, maar dit nooit goed magtig geword nie:

En ons het daarby van Hollands gepraat en ons het daarby nooit Nederlands bedoel nie. Ons het altyd Afrikaans bedoel en die feit dat ek hier Afrikaans mag praat, sit die stempel op ons taal. (Anon. 1925a, kol. 78)

Dit blyk egter uit Hertzog se toespraak dat sy gebruik van die benamings verwarrend bly. Hy sê:

Ek weet dat ek lank'n sondaar gewees het teen die Afrikaans en ek altyd Hollands gepraat het tot drie of vier jaar gelede toe ek aan myself gesê het: nee, dit moet nou verander. (Anon. 1925a, kol. 78)

Hier gebruik hy dus weer Hollands in die betekenis van Nederlands.

Dit gebeur ook in sy reaksie op 'n opmerking van 'n ander Volksraadslid, Joël Krige van Caledon: 'Dit het swaar gegaan' [met die Afrikaans praat]. Hertzog het geantwoord:

Ja, dit het swaar gegaan, want ek is in Hollands [Nederlands] opgevoed. Ek is egter bly om te sê dat ek my hier vandag kan bedien van my eie taal sonder om te soek na woorde of sinne en wat Suid-Afrika betref, bestaan daar vir my geen twyfel meer nie dat as ons van Hollands praat ons niks anders as ons eie taal bedoel nie. (Anon. 1925:kolom 78-79)

Die gesamentlike komitee het van 24 Februarie tot 12 Maart 1925 agt keer byeengekom met F.W. Reitz as voorsitter. Langenhoven en Malan het die meeste vrae gestel. Op 'n gesamentlike sitting van die Volksraad en die Senaat op 08 Mei 1925 is 'n wetsontwerp goedgekeur waarvan die eerste bepaling soos volg lui:

Het woord 'hollandse' in artikel honderd zeven en dertig van de Zuid-Afrika Wet, 1909, en elders in die Wet waar dat woord voorkomt, wordt hierbij verklaard het Afrikaans in te sluiten. (Anon. 1925b:25)

In 'n tweede bepaling word gespesifiseer die eerste bepaling 'wordt geacht van kracht geweest te zijn vanaf de een en dertigste dag van Mei 1910'.

\section{Slot: Die eerste stap na amptelike veeltaligheid}

Wat die besluit van 20 Oktober 1908 van soveel historiese belang maak, is dat dit 'n eerste stap op die weg na amptelike meertaligheid was. Die imperialistiese idee van 'een land, een nasie, een taal' en dus amptelike eentaligheid, moes plek maak vir amptelike tweetaligheid. Een na die ander inheemse tale het mettertyd amptelike status verwerf. Die eerste was Afrikaans. Al het die daaropvolgende stappe ook binne 'n heel ander staatkundige konteks gevolg (die gepoogde wegbeweging van die eenheidstaat wat die Unie van SuidAfrika en die 1961-Republiek van Suid-Afrika was), het verskeie ander inheemse tale regionale amptelike status verkry. Dit was 'n uitvloeisel van die tuislandbeleid. Regte is aan hierdie tale toegeken nadat die taalklousule van die 1961-grondwet gewysig is. Daardie taalklousule het dieselfde as artikel 137 van die Zuid-Afrika Wet van 1909 behels. Dat hierdie tale de facto-amptelike tale was, is ook deur die African National Congress (ANC) erken en tydens die onderhandelings vir 'n nuwe grondwet in 1993 gevolg. In een stadium is voorgestel dat slegs Afrikaans en Engels amptelike tale of 'dokumentstale' word, maar die ANC se argument daarteen was dat wette in Transkei ook in Xhosa geskryf word (Steyn 1995:114-115).

Die vernaamste oorweging van Afrikaner-taalaktiviste tussen 1875 en 1925 was om 'n beleid en praktyke te ontwikkel wat sou verhoed dat Engels die enigste amptelike taal en onderwystaal van Suid-Afrika word. In hierdie proses was Nederlands 'n belangrike werktuig. Soos S.J. du Toit in die vooruitsig gestel het, het die bevordering van Nederlands die bevordering van Afrikaans ingehou. Die skrywer M.E.R. gebruik die bloeiwyse van die Yslandpapawer as beeld van hierdie proses. Aanvanklik beskerm die omhulsels van die knoppe die blom:

...maar as die ontplooiingstyd daar is, moet die omhulsel, wat nie meer kan beskerm nie, noodwendig afval. So het die Nederlandse taal onse Afrikaans teen beskadiging van buite omhul en beskerm en laat groei; en toe die volle wasdom daar was en die volksgevoel die warmte vir ontplooiing verleen, het dit afgeval. (Rothmann 1972:102)

Nadat Du Toit, Hertzog en Steyn vir Hollands (Nederlands) geveg het, het De Waal en Langenhoven dit help afskaf. Dit is merkwaardig dat die Nederlandse taal nie alleen gehelp het om Afrikaans te beskerm nie, maar dat die benaming Hollands Afrikaans in staat gestel het om staatkundig erken te word.

\section{Erkenning Mededingende belange}

Die outeur verklaar hiermee dat hy geen finansiële of persoonlike verbintenis het met enige party wat hom voordelig of nadelig kon beïvloed het in die skryf van hierdie artikel nie.

\section{Literatuurverwysings}

Anon., 1882, Die Afrikanerbond, D.F. du Toit, Paarl.

Anon., 1925a, Debatte van die Volksraad, tweede sitting - vyfde parlement, deel 3, Nasionale Pers, Kaapstad.

Anon., 1925b, Statuts of the Union of South Africa 1925: Wetten van de Unie van ZuidAfrika 1925, Goewermentsdrukker, Kaapstad.

Carstens, W., 2018, Gaan ons uiteindelik 'n/die Derde Afrikaanse Taalbeweging beleef? LitNet, Seminare en essays.

Cilliers, D.H., 1953, Die stryd van die Afrikaanssprekende in Kaapland om sy eie skool (1652-1939), Balkema, Kaapstad.

De Villiers, 1936, 'Anna J.D., Die Hollandse taalbeweging in Suid-Afrika', in Annale van die Universiteit van Stellenbosch XIV, Nasionale Pers, Kaapstad.

De Waal, J.H.H., 1939, My herinnerings van ons taalstryd. Versamelde werke, Deel I, Nasionale Pers, Kaapstad. 
De Wet, C., Van Heyningen, E. \& Van der Merwe, C. (vertaler), 2017, Seleksies uit die briewe van president M.T. Steyn 1904-1910 [Selections from the letters of President M.T. Steyn 1904-1910], Van Riebeeck-Vereniging, Kaapstad.

Du Plessis, T., 2004, 'Afrikaans en taalaktivisme', in F.I.J. van Rensburg (red.), Afrikaans - Lewende taal van miljoene, bl. 169-182.

Du Toit, J.D., 1917 [1960], 'Ds. S.J. du Toit in weg en werk', in J.D. du Toit, Versamelde werke van Totius, deel 1, bl. 1-510, Dagbreek-Boekhandel, Johannesburg.

Du Toit, S.J., 1909, Geskidenis fan di Afrikaanse Taalbeweging, 2e druk, Paarl DrukpersMaatschappij, Paarl.

Giliomee, H., 2004, Die Afrikaners: 'n Biografie, Tafelberg, Kaapstad.

Hancock, W.K. \& Van der Poel, J., 1966, Selections from the Smuts papers, pt. 2, Cambridge University Press, Cambridge. https://doi.org/10.1017/CBO9780511563638; https:// doi.org/10.1017/CBO9780511563614; https://doi.org/10.1017/СBO9780511563621

Langenhoven, C.J., 1956, 'My aandeel aan die taalstryd', in C.J. Langenhoven, Versamelde Werke, Deel12, bl. 301-422, Nasionale Pers, Kaapstad.

Le Roux, T.H, Malherbe, D.F. \& Smith, J.J., 1917, Afrikaanse Woordelijs en Spelreëls, faksimilee-uitgawe, Protea Boekhuis, Pretoria.

Le Roux, J.H., Coetzee, P.W. \& Marais, A.H. (reds.), 1987, Generaal J.B.M. Hertzog: Sy strewe en stryd, vol. 1, Perskor, Johannesburg.

Luther, J., Pheiffer, F. \& Gouws, R.H. (reds.), 2015, HAT: Handwoordeboek van die Afrikaanse Taal, 6e uitg., Pearson, Kaapstad.

Nienaber, G.S., 1952, 'Artikel 137 van die Unie-grondwet', Hertzog-Annale 1(1), 64-71.
Preller, J.F., 1951, Die Konvensie-dagboek van sy edelagbare Francois Stephanus Malan 1908-1909, Van Riebeeckvereniging, Kaapstad.

Rothmann, M.E., 1972, My beskeie deel, Tafelberg, Kaapstad.

Scholtz, G.D., 1977, Die ontwikkeling van die politieke denke van die Afrikaner, Deel 4 1881-1899, Perskor, Johannesburg.

Scholtz, G.D., 1979, Die ontwikkeling van die politieke denke van die Afrikaner, Deel 6: 1910-1924, Perskor, Johannesburg.

Scholtz, J. du P.,1965. Die Afrikaner en sy taal 1806-1875, 2e druk, Nasou, Kaapstad. Spies, F.J. du T., Krüger, D.W. \& Oberholster, J.J. (reds.), 1977, Die Hertzogtoesprake, Deel 1, Perskor, Johannesburg.

Steyn, J.C., 1995, 'Die taalstryd in die oorgangstyd, Supplement 1', Stilet, April.

Steyn, J.C., 2014, Ons gaan "n taal maak': Afrikaans sedert die Patriot-jare, Kraal, Pretoria.

Thompson, L.M., 1960, The unification of South Africa, Clarendon, Oxford.

Van den Heever, C.M., 1944, Generaal J.B.M. Hertzog, A.P.-Boekhandel, Johannesburg.

Van der Merwe, N.J., 1921. Marthinus Theunis Steyn, 'n lewensbeskrywing, Deel 2 Nationale Pers, Kaapstad.

Van Rensburg, C., 2017, 'Die totstandkoming van die eerste Afrikaanse Woordelijs en spelreëls', in T.H. le Roux, D.F. Malherbe \& J.J. Smih, Afrikaanse Woordelijs en spelreëls, faksimilee-uitgawe, Protea Boekhuis, Pretoria.

Von Wielligh, G.R., 1922, Eerste skrywers, Van Schaik, Pretoria. 